\title{
Corporate structure and the informativeness of provision management: evidence from the Netherlands
}

\author{
Citation for published version (APA):
}

Peek, E. (2000). Corporate structure and the informativeness of provision management: evidence from the Netherlands. METEOR, Maastricht University School of Business and Economics. METEOR Research Memorandum No. 043 https://doi.org/10.26481/umamet.2000043

Document status and date:

Published: 01/01/2000

DOI:

10.26481/umamet.2000043

Document Version:

Publisher's PDF, also known as Version of record

\section{Please check the document version of this publication:}

- A submitted manuscript is the version of the article upon submission and before peer-review. There can be important differences between the submitted version and the official published version of record. People interested in the research are advised to contact the author for the final version of the publication, or visit the DOI to the publisher's website.

- The final author version and the galley proof are versions of the publication after peer review.

- The final published version features the final layout of the paper including the volume, issue and page numbers.

Link to publication

\footnotetext{
General rights rights.

- You may freely distribute the URL identifying the publication in the public portal. please follow below link for the End User Agreement:

www.umlib.nl/taverne-license

Take down policy

If you believe that this document breaches copyright please contact us at:

repository@maastrichtuniversity.nl

providing details and we will investigate your claim.
}

Copyright and moral rights for the publications made accessible in the public portal are retained by the authors and/or other copyright owners and it is a condition of accessing publications that users recognise and abide by the legal requirements associated with these

- Users may download and print one copy of any publication from the public portal for the purpose of private study or research.

- You may not further distribute the material or use it for any profit-making activity or commercial gain

If the publication is distributed under the terms of Article $25 \mathrm{fa}$ of the Dutch Copyright Act, indicated by the "Taverne" license above, 


\title{
Corporate Structure and the Informativeness of Provision Management: Evidence from the Netherlands
}

\author{
Erik Peek* \\ Department of Accounting and Auditing \\ Faculty of Economics and Business Administration \\ Maastricht University \\ P.O. Box 616 \\ 6200 MD Maastricht \\ The Netherlands \\ email: e.peek@berfin.unimaas.nl
}

MARC Working Paper

MARC-WP/3/2000-05

\footnotetext{
${ }^{*}$ The author gratefully acknowledges the contribution of I/B/E/S International Inc. for providing earnings per share forecast data, available through the Institutional Brokers Estimate System. This data has been provided as part of a broad academic program to encourage earnings expectations research. The author appreciates helpful comments and suggestions from Jan Klaassen, Frederick Lindahl, Frank Moers and Ruud Vergoossen.
} 


\title{
Corporate Structure and the Informativeness of Provision Management: Evidence from the Netherlands
}

\begin{abstract}
This study considers the influence of Dutch governance structures on the informativeness of reported unexpected changes in provisions. Characteristics of the corporate governance system in the Netherlands provide a unique opportunity to investigate the influence of characteristics of the governance system on market reactions to financial disclosures. This governance system allows a distinction between structure companies, where supervisors' disciplinary power is high, and nonstructure companies, where supervisors' disciplinary power is low. Characteristics of the Dutch financial accounting system are comparable to those of Anglo-Saxon systems. I investigate investors' response to the disclosure of unexpected changes in provisions by means of an event study which focuses on the abnormal stock returns during two days surrounding the disclosure date. Additionally, I examine analysts' forecast revisions around the disclosure date by using I/B/E/S earnings forecasts. The empirical evidence indicates that unexpected provisions are positively associated with abnormal stock returns and abnormal forecast revisions, suggesting that non-structure companies use unexpected changes in provisions to signal future performance. The positive relationship between unexpected changes in provisions and the market reaction is more pronounced when my proxy for information asymmetry is high. Furthermore, I find that unexpected changes in provisions of structure companies are significantly less informative. I argue that this is attributable to the fact that supervisors of structure companies exercise more discipline over company management than supervisors of non-structure companies.
\end{abstract}

Key words: Provisions, earnings management, corporate governance. 


\section{INTRODUCTION}

Previous research suggests that governance structure and board effectiveness are important determinants of management's use of discretion in financial reporting. Concentrated stock ownership, managerial stock ownership and board effectiveness play an important role in restraining earnings management (Beasley 1996; Dechow et al. 1996; Peasnell et al. 1998; Warfield et al. 1995). Recent discussions on the effectiveness of the Anglo-Saxon corporate governance systems and the growing awareness that alternative governance systems, such as those in Germany and Japan, provide effective control mechanisms (see, for example, Roe 1994; Shleifer and Vishny 1997), indicate that attention for the influence of non-AngloSaxon governance systems on management's discretion in financial reporting is warranted.

This study considers the influence of Dutch governance structures on the informativeness of reported unexpected changes in provisions. Using provision data of Dutch listed companies, I assess whether investors' and financial analysts' reactions to companies' disclosure of unexpected changes in provisions depend on characteristics of these companies' Supervisory Boards. Unique properties of the corporate governance system in the Netherlands provide the opportunity to investigate the effect of differences in supervisors' disciplinary power over company management on the market's interpretation of financial disclosures. The main characteristics of the Dutch financial accounting system are comparable to those of Anglo-Saxon accounting systems. For instance, the alignment of Dutch tax accounting and financial accounting is low; the Netherlands have a private accounting standard setting body; Dutch spending on audit services is high; and, the Dutch common stock and bond markets are

well-developed (see Mueller et al. 1994). ${ }^{1}$ Furthermore, prior research indicates that Dutch financial reporting is relatively informative (Alford et al. 1993). 
Based on the legal regimes provided by Dutch regulation governing the corporate structure of public companies I make a distinction between structure companies and non-structure companies. Structure companies differ from non-structure companies in that only supervisors of structure companies have the authority to appoint and dismiss management, amend the annual statements and veto strategic decisions. In this paper I argue that this causes the disciplinary power of structure companies' supervisors to be greater than the disciplinary power of non-structure companies' supervisors, affecting management's accounting decisions.

The sample used in this study consists of provision data available from the annual reports of 90 firms that have been listed on the Amsterdam Stock Exchange from 1989 to 1997. The examined provisions include provisions that are highly discretionary, such as provisions for maintenance costs and provisions for underinsured property. I investigate investors' response to the disclosure of unexpected changes in provisions by means of an event study which focuses on the abnormal stock returns surrounding the disclosure date. Additionally, I examine analysts' forecast revisions around the disclosure date by using I/B/E/S earnings forecasts. The empirical evidence is consistent with the idea that unexpected changes in provisions of non-structure companies convey management's private information about expected future profitability. Unexpected changes in provisions of these companies are positively associated with abnormal stock returns and abnormal forecast revisions, indicating that provisions are informative. Furthermore, I find that unexpected changes in provisions of structure companies are significantly less informative. I argue that this is attributable to the fact that supervisors of structure companies exercise more discipline over company management than supervisors of non-structure companies due to differences in their formal authorities, thereby restraining management's discretion in reporting provisions.

This study contributes to the earnings management literature in several respects. First, it 
examines informative earnings management in a country where financial reporting is flexible but where reported earnings are found to be relatively informative and forecast accuracy is found to be relatively high (Alford et al. 1993; Capstaff et al. 1996; Basu et al. 1998). Second, the empirical analysis avoids the problems associated with discretionary accrual estimation by focusing on largely discretionary provisions. Third, the study adds to previous research on the influence of governance structures on earnings management. Governance structures in the Netherlands provide a unique opportunity to investigate the influence of characteristics of the corporate system on market reactions to financial disclosures.

The remainder of this paper is organized as follows. The next section develops hypotheses and discusses the research design. Section 3 addresses the sample selection procedures and variable definitions. Section 4 describes the empirical results. Concluding comments appear in section 5 .

\section{Hypotheses DEVELOPMENT AND RESEARCH DESIGN}

\section{(i) Provision management}

A substantial amount of literature discusses managers' discretion regarding reported earnings. Many previous studies focus on single-year earnings management when managers use discretion in financial reporting to influence stakeholders' perception of the company's current financial performance. For instance, Healy (1985) and Holthausen et al. (1995) investigate whether managers manipulate accruals in order to maximize their earnings-based compensation, Jones (1991) focuses on managers' earnings management activities to affect the outcomes of import relief investigations, and DeFond and Jiambalvo (1994), and Sweeney (1994) suggest that companies manage earnings in order to avoid violating debt-covenants. Some studies take 
a more general approach by investigating whether under all circumstances managers have an economic or psychological incentive to exceed certain thresholds, such as prior year earnings or financial analysts' consensus earnings forecast (Burgstahler and Dichev 1997; Degeorge et al. 1998).

The central idea underlying these studies is that management bases its accrual decisions on the earnings level in the current fiscal year. These decisions therefore do not convey information about management's estimate of future earnings and cause current reported accruals to be less informative. On the contrary, discretionary accruals can be informative to investors and financial analysts when these accruals are systematically associated with future financial performance. This may occur, for example, when managers smooth reported earnings in anticipation of future earnings (see DeFond and Park 1997) or when managers use the discretionary component of provisions to signal future profitability (see e.g. Wahlen 1994).

This paper concerns the informativeness of the discretionary component in Dutch companies' provisions. It assumes that these discretionary components can convey private information about future profitability in two different ways. The first way is that management decreases (increases) discretionary accruals when it expects that future earnings will be lower (higher) than current earnings (hereafter referred to as earnings smoothing). DeFond and Park (1997) find empirical support for this type of earnings management where managers smooth earnings in anticipation of future earnings. In their view managers' rationale for this type of earnings management is that they avoid reporting low earnings that could have resulted in dismissal by borrowing from the future, and conversely, save for future bad times when current performance is good. The central idea underlying the study of DeFond and Park (1997) is that the monitors of the company focus much more on current performance than on past performance in evaluating company management (see also Fudenberg and Tirole 1995). 
This results in the fact that aligning current reported earnings with previously reported earnings is less useful to managers than aligning current reported earnings with future expected earnings by borrowing from or saving for the future when necessary.

If management exercises its discretion in this particular way and consistently over time, reported earnings will ultimately be less variable than reported earnings in absence of manipulation. Motivations for earnings smoothing that are based on reductions in earnings variability have been offered by Lev and Kunitzky (1974) and Trueman and Titman (1988). They argue that earnings smoothing may be profitable as soon as outsiders are no longer able to differentiate between 'accounting' smoothing and 'real' smoothing. Real smoothing affects risk measures and could therefore have economic consequences.

The second way in which management can communicate private information about future performance is by strategically disclosing or withholding good versus bad news (hereafter referred to as signalling). In this context companies that expect good (poor) future performance voluntarily choose income-decreasing (income-increasing) accruals (see Teoh and Hwang 1991; Healy and Palepu 1993; Frantz 1999). Credible signalling can only occur when the costs of the signal increases as a function of the size of the signal and when these costs are lower for companies expecting good future performance than for companies expecting poor future performance. Such a situation can arise when changes in provisions affect management's earnings-based compensation. ${ }^{2}$ Several studies provide empirical evidence that management exercises its discretion in this way. For instance, Wahlen (1994) finds that increases in unexpected loan loss provisions signal good news and are associated with a positive stock market reaction. Other examples are the studies that find that announcements of discretionary restructuring charges lead to positive market reactions (e.g. Bunsis 1997; Brickley and Van Drunen 1990), or positive revisions of long-horizon growth forecasts (Chaney et al. 1999). 
Dutch legislation on the use of provisions is fairly flexible and therefore provides a setting in which many provisions are highly discretionary. In general, in determining provisions managers should adhere to the following two rules: (1) risks or contingencies causing the recognition of a provision must be specific, and (2) the future financial impact must be reasonably estimable. Although future losses and liabilities have to be probable, Dutch regulation requires no further (quantitative) specifications with respect to the likelihood that an event will occur. This study considers provisions for warranty costs, provisions for underinsured property, provisions for maintenance costs and non-specified 'other' provisions. Provisions for maintenance costs, which purpose is to spread expenses for major maintenance over years, and provisions for underinsured property are highly discretionary and not allowed under International Accounting Standards or US GAAP. This makes these provisions extremely useful in studying the phenomena of earnings smoothing and signalling described above. Dutch companies also have considerable discretion in reporting 'other' provisions, since these consist of different provisions of which only the nature is specified in the notes to the annual statements. Although the separate components of other provisions are small, in aggregate these provisions can have a significant impact on reported earnings. In the sample under examination in this study absolute values of changes in other provisions are $13.5 \%$ of net income on average (median 2.0\%).

Consistent with Dutch regulation and International Accounting Standards I define provisions as an estimated liability. This means that increases in provisions are equivalent to negative accruals and decreases in provisions are equivalent to positive accruals. I further define expected changes in provisions as changes in provisions that investors and analysts can expect on the basis of the information that is available to them about a company's change in operating activity or asset base. 
Management has discretion in recognizing unexpected changes in provisions. With respect to the recognition of unexpected changes in provisions, managers who aim to smooth earnings minimize the recognized changes in provisions when they expect that earnings will increase next year and maximize the recognized changes when they expect that earnings will decrease next year. Managers who engage in signalling display the opposite behaviour. Signalling would result in a situation where only companies that expect next year's earnings to decrease ('bad news' companies) report unexpected decreases in provisions and only companies that expect next year's earnings to increase ('good news' companies) report unexpected increases in provisions. The signalling theory therefore predicts that reported unexpected changes in provisions are positively associated with expected changes in earnings. Earnings smoothing would result in a situation where only 'bad news' companies report unexpected increases in provisions and only 'good news' companies report unexpected decreases in provisions. The earnings smoothing theory therefore predicts that reported unexpected changes in provisions are negatively associated with expected changes in earnings. According to both theories 'bad news' companies and 'good news' companies can decide not to recognize unexpected changes in provisions. Reporting no unexpected changes in provisions therefore does not convey information about future profitability.

I do not have prior expectations on managers' choice between earnings smoothing or signalling. However, in the next sections I argue that differences in corporate structure and board effectiveness of Dutch companies affect the extent to which Dutch managers engage in informative provision management. 


\section{(ii) Governance structures}

The corporate governance system in the Netherlands has some characteristics that are unique in an international perspective. In conformity with some other continental European companies, Dutch companies generally have a two-tier board structure. The existence of a Management Board and a Supervisory Board implies that executive and supervisory (monitoring) responsibilities are formally separated. Dutch regulation governing the corporate structure of public companies differs from regulation in other continental European countries in that it provides four alternative legal regimes: (i) the structure regime, (ii) the mitigated structure regime, (iii) the exempted regime, and (iv) the common regime. The structure law, which introduced these regimes in 1971, governs the corporate structure of Dutch companies with more than 100 employees and common equity in excess of 25 million (GLD). In short, this law devolves the following authorities of common shareholders to the Supervisory Board: (1) the authority to appoint and dismiss management, and (2) the right to make amendments to the annual financial statements. Furthermore, the Supervisory Board obtains the right to veto strategic decisions made by the Management Board, such as new equity issues, large investments, or massive dismissal.

Companies with more than 100 employees and common equity in excess of 25 million may be exempt from the structure law because of one of the following two reasons. First, the respective companies are the corporate headquarters of a multinational corporation and employ more than $50 \%$ of their employees outside the Netherlands. The exempted regime applies to these companies. Second, the respective companies are part of a multinational corporation and employ more than $50 \%$ of their employees outside the Netherlands. The mitigated structure regime applies to these companies. The common regime applies to companies with less 
than 100 employees or common equity less than 25 million (GLD). Companies exempt from the structure law may voluntarily choose to be a structure company.

For the purpose of this study it is sufficient to make a distinction between structure companies, i.e. those companies that are subject to the structure regime, and non-structure companies, i.e. those companies that are subject to the common regime, the mitigated structure regime or the exempted regime. In this context structure companies differ from non-structure companies in that only supervisors of the former type of companies have the authority to dismiss management and the right to make amendments to the annual statements. Supervisors of non-structure companies can suspend managers from their office, however, shareholders of these companies retain the ultimate authority to dismiss the managers. Approximately $75 \%$ of the listed Dutch companies are structure companies.

Table 1 summarizes the differences between structure companies and non-structure companies. The fourth column of table 1 (Appointment) shows an additional difference between the four regimes. Members of the Supervisory Board of all companies represent different groups of stakeholders and are legally bound to act in the interests of all stakeholders (e.g. creditors, employees, shareholders). However, only supervisors of companies that are subject to the common regime or the exempted regime are elected at the General Shareholders' Meeting. Supervisors of companies that are subject to the structure regime or the mitigated structure regime are appointed by co-optation. This may influence the orientation of the Supervisory Board. Since the Dutch law prescribes that supervisors can only be dismissed by those who have appointed them, supervisors of non-structure companies, who are elected by shareholders, are more likely to act in the interests of shareholders than supervisors of structure companies, who are appointed by co-optation. ${ }^{3}$ Furthermore, appointing by co-optation may shield supervisors from management's power and insulate them against ejection after 
an unsuccessful dissent, increasing the frequency of open dissent from the Supervisory Board and consequently increasing board effectiveness (Warther 1998).

[Table 1 about here.]

The fifth column of table 1 (Board effectiveness) shows my expectations on the consequences of the differences between structure companies and non-structure companies for supervisors' disciplinary power over company management. I expect that supervisors of structure companies can exercise more effective discipline over company management than supervisors of non-structure companies. The reason for this is that the Supervisory Board of structure companies can effectively impose restrictions on management's discretion by threatening to veto strategic decisions, amend the financial statements or dismiss management. ${ }^{4}$ Appointment by co-optation further increases board independence and board effectiveness, as argued above.

Since supervisors' ability to effectively monitor management of non-structure companies is limited, the question arises whether alternative disciplinary mechanisms are present to control management of these companies. In the Netherlands hostile takeovers rarely occur since Dutch companies dispose of a wide range of takeover defence mechanisms. ${ }^{5}$ Therefore, the market for corporate control is virtually nonexistent. It is also not likely that Dutch common shareholders effectively monitor company management. First, disciplinary power of common shareholders is low since they are fragmented and generally have a passive attitude that is partly the consequence the accepted takeover defence mechanisms, limiting their voting power. Second, some non-structure companies allow holders of priority shares, which are issued to a friendly foundation, to make binding recommendations to the General Shareholders' Meeting for the appointment of members of the Management Board and Supervisory Board. As a re- 
sult shareholders' influence on board composition is limited and the Management Board may dominate the election of supervisors. These restrictions on the disciplinary role of the Dutch market for corporate control and the General Shareholders' Meeting suggest that the Supervisory Board remains the most relevant monitoring mechanism of non-structure companies, although its effectiveness is expected to be low, as argued above.

In summary, this study makes a distinction between structure companies and non-structure companies. Structure companies differ from non-structure companies in that the Supervisory Board of structure companies is more independent and has higher disciplinary power over company management than the Supervisory Board of non-structure companies. These unique properties of the Dutch corporate systems offer the opportunity to effectively measure the efficacy of outsiders' supervision and avoid the use of proxies such as the proportion of outside members on the Executive Board, the presence of an external blockholder, or managerial ownership (see e.g. Warfield et al. 1995; Dechow et al. 1996; Beasley 1996).

\section{(iii) Hypotheses and research design}

The objective of this study is to investigate whether corporate structure influences the extent to which Dutch listed companies make use of the discretionary component in provisions to communicate private information to shareholders. The study implicitly assumes that when possible, managers use their discretion in financial reporting to reduce the degree of information asymmetry between management and shareholders, as evidenced, amongst others, by Subramanyam (1996), Bartov and Bodnar (1996) and Beatty and Harris (1998). Managers' incentive to do so is that improved communication with shareholders is beneficial to the company since it corrects mispricing and reduces the company's cost of capital (see e.g. Healy and Palepu 1993). 
Based on the idea that reported unexpected changes in provisions are informative to investors and analysts, I predict that unexpected changes in provisions are associated with abnormal stock returns and analysts' abnormal forecast revisions, either positively (signalling) or negatively (earnings smoothing). However, I expect that the informativeness of provision management decreases when the effectiveness of the Supervisory Board increases. Using unexpected changes in provisions for the purpose of earnings smoothing or signalling implies that under certain conditions companies should aggressively recognize unexpected decreases in provisions. Powerful Supervisory Boards most likely force management to report conservatively, i.e. only recognize unexpected increases in provisions, thereby not allowing management to use provisions for the purpose of earnings smoothing or signalling. This implies that reported unexpected changes in provisions of companies with powerful, effective supervision are not informative and therefore not associated with abnormal stock returns and abnormal forecast revisions. The idea that effective boards restrain earnings management is consistent with the empirical results of Beasley (1996), Dechow et al. (1996) and Peasnell et al. (1998).

In the previous section I argued that structure companies have more effective Supervisory Boards than non-structure companies. I therefore predict that provision management of nonstructure companies is more informative than provision management of structure companies. The following hypothesis applies:

$\mathrm{H}_{1}$ : Unexpected changes in provisions of structure companies are less informative and therefore less associated with abnormal stock returns and analysts' abnormal forecast revisions around the announcement of provisions than unexpected changes in provisions of non-structure companies.

Alternatively, since the authority to dismiss management of structure companies is in 
the hands of a powerful, effective Supervisory Board, managers of structure companies may have stronger incentive to smooth reported earnings relative to managers of non-structure companies, as suggested by DeFond and Park (1997) and Fudenberg and Tirole (1995). If stricter oversight does not reduce the opportunity to manage provisions, unexpected changes in provisions of structure companies can be negatively associated with abnormal stock returns and abnormal forecast revisions.

The central idea underlying hypothesis 1 is that managers use their discretion to communicate with shareholders and reduce the degree of information asymmetry. This suggests that unexpected changes in provisions are more informative when the degree of information asymmetry and the need for improved communication is high. Additionally, Holthausen and Verrecchia (1988) indicate that the market response to an information release should increase as a function of the level of uncertainty about a company's future performance prior to the information release. Therefore, I expect that the market reaction to unexpected changes in provisions of non-structure companies increases with the degree of information asymmetry.

$\mathrm{H}_{2}$ : The market reaction to unexpected changes in provisions of non-structure companies is more pronounced when the degree of information asymmetry between management and shareholders is high.

I have no prior expectation on the relationship between the degree of information asymmetry and the market reaction to unexpected changes in provisions of structure companies. When supervisors of structure companies discourage informative provision management in all circumstances, the market reaction is not associated with the degree of information asymmetry. ${ }^{6}$

In order to investigate the stock market reaction to the disclosure of unexpected changes 
in provisions, I estimate the following equation using provision data of 90 companies that were publicly listed on the Amsterdam Stock Exchange from 1989 to 1997:

$$
\mathrm{AR}_{\mathrm{it}}=\alpha_{0}+\alpha_{1} \Delta \mathrm{E}_{\mathrm{it}}+\alpha_{2} \mathrm{UP}_{\mathrm{it}}+\alpha_{3} \mathrm{INFOASYM}_{\mathrm{it}}+\alpha_{4} \mathrm{INFOASYM}_{\mathrm{it}} \mathrm{UP}_{\mathrm{it}}+\varepsilon_{\mathrm{it}}
$$

in which $\mathrm{AR}_{\text {it }}$ denotes the cumulative abnormal stock return on the day of and the first day after the disclosure of the annual financial statements, $\Delta \mathrm{E}_{\mathrm{it}}$ equals the annual change in reported earnings before adjustments to provisions, and $\mathrm{UP}_{\text {it }}$ denotes the size of unexpected changes in provisions. Both independent variables are scaled by lagged total assets. INFOASYM $_{\text {it }}$ is a variable that proxies for the degree of information asymmetry between managers and shareholders. The earnings variable should control for the effect of the earnings announcement. It is likely that a large part of the earnings information has already been incorporated into stock prices, since most companies make preliminary earnings announcements before the disclosure date of the financial statements. In a second regression I replace $\mathrm{AR}_{\mathrm{it}}$ with $\mathrm{UREV}_{\mathrm{it}}$, which denotes financial analysts' abnormal earnings forecast revision. In the next section I will explain in further detail the estimation of the variables used in the regression analysis.

In this study I avoid making arbitrary assumptions about the expected behaviour of accruals by focusing on largely discretionary provisions and by assuming that market participants are able to at least partly capture the information that is conveyed by managers' manipulations of provisions. This implies that when provisions are managed in particular situations, share price reactions and earnings forecast revisions may differ in these situations, as described above. I realize that it is possible that the assumption about market participants' abilities to interpret the effect of earnings management is not valid, which may weaken the empirical 
results. For example, Bartov et al. (1998) indicate that investors do not fully understand the cash flow implications of write-offs. However, the analysis will capture the effect of earnings management as soon as investors and analysts suspect that management manipulates provisions and immediately act on their suspicion. Hence, the analysis does not require full understanding of the economic consequences.

\section{SAMPle SELECTION AND VARIABLE DEFINITIONS}

\section{(i) Earnings forecasts and share prices}

The analysis of financial analysts' response to unexpected changes in provisions concerns analysts' abnormal forecast revisions in the first two months after the announcement date. The necessity to estimate abnormal forecast revisions follows from the following two characteristics of analysts' revisions. First, since financial analysts do not revise their estimates in every month, forecast revisions are generally serially correlated. That is, if all analysts revise their earnings' forecasts every five months on average, approximately $80 \%$ of the information that they incorporate into their forecast revisions has been released in the previous four months and has consequently been reflected in previous forecast revisions. ${ }^{7}$ Second, evidence exists that analysts are positively biased but systematically lower their forecasts when the forecast horizon decreases. In sum, this implies that monthly revisions are (1) negative on average and (2) to some extent based on information that is released in previous months. Therefore, I estimate abnormal revisions using the following procedure (see also Brous and Kini 1993).

First, I use the individual earnings forecasts provided by I/B/E/S to construct monthly consensus forecasts from 1989 to 1997. In this study these months do not run parallel with calendar months but are defined as four week periods centred on the announcement date. 
I compute the consensus forecasts by averaging the individual forecasts, where I include individual forecasts up to the month in which a revised forecast is submitted. The consensus forecast revision $\left(\mathrm{REV}_{\mathrm{it}}\right)$ of firm $i$ in month $t$ has the following definition:

$$
\mathrm{REV}_{\mathrm{it}}=\frac{\mathrm{F}_{\mathrm{it}}-\mathrm{F}_{\mathrm{i}, \mathrm{t}-1}}{\mathrm{P}_{\mathrm{iy}}}
$$

in which $\mathrm{F}_{\mathrm{it}}$ and $\mathrm{P}_{\mathrm{iy}}$ denote the consensus earnings per share forecast in month $t$ and share price of firm $i$ at the beginning of the fiscal year $y$.

Second, I divide the consensus revision into an abnormal and an expected component. The expected forecast revisions has the following definition (cf. Brous and Kini 1993):

$$
\mathrm{EREV}_{\mathrm{it}}=\mathrm{EBIAS}_{\mathrm{i}}+\Sigma_{\mathrm{n}=1}^{4} 0.2 \mathrm{UREV}_{\mathrm{i}, \mathrm{t}-\mathrm{n}}
$$

in which EBIAS $_{\mathrm{i}}$ equals the average revisions during the estimation period consisting of months -6 to 6 , and $\mathrm{UREV}_{\mathrm{i}, \mathrm{t}-\mathrm{n}}$ denotes the abnormal revision in month $t$ - $n$. Since analysts appear to revise their estimates every five months on average, I expect that forecast revisions of month $t$ are correlated with revisions of months $t-4$ to $t$ - 1 . The expected forecast revisions thus equals the sum of the average revision EBIAS $\mathrm{i}_{\mathrm{i}}$ and the weighted average of the unexpected forecast revisions of the previous four months, where I assign these equal weights (0.2).

This study also considers the abnormal stock market reaction to the disclosure of provisions. Share prices come from Datastream. Daily stock returns have the following definition:

$$
\mathrm{R}_{\mathrm{ik}}=\frac{\mathrm{P}_{\mathrm{ik}}-\mathrm{P}_{\mathrm{i}, \mathrm{k}-1}}{\mathrm{P}_{\mathrm{i}, \mathrm{k}-1}}
$$

in which $\mathrm{P}_{\mathrm{ik}}$ denotes the share price of firm $i$ at day $k$. Daily abnormal stock returns equal the difference between the observed stock returns and expected stock returns based on a market model. I estimate the market model parameters over a 140-trading-day period which ends 25 days prior to the announcement date. ${ }^{8}$ The source of the event dates is Het Financieele 
Dagblad, a Dutch daily financial newspaper. I assume that the dates of the announcements of unexpected provisions correspond with the dates of publication of the annual financial statements.

The variability of the abnormal stock returns estimated as the residuals of the market model represent the nonsystematic risk of the firm's stock. Since the level of nonsystematic risk is firm-specific, the use of Ordinary Least Squares regressions likely produces firm-specific variances of the error term and yields inefficient parameter estimates. Therefore, I use Generalized Least Squares regressions, where I weight the dependent and independent variables with the (firm-year-specific) standard deviation of the daily abnormal returns during the estimation period.

A similar argument holds when abnormal revisions are the dependent variable. When financial analysts have heterogeneous beliefs about a firm's future performance, they may not react unequivocally to publicly released information. The variance of the error term of OLS regressions therefore depends on the idiosyncrasy of analysts' perceptions of the observed event. Abnormal forecast revisions reflect analysts' interpretation of new information but also the extent to which analysts' interpretation of previously disclosed information in month $t$ differs from analysts' interpretation in month $t-n$. Hence, high variance of abnormal forecast revisions probably implies that analysts' beliefs about the future prospects of a firm are heterogeneous. In the forecast revision regressions I therefore weight the dependent and independent variables with the (firm-year-specific) standard deviation of analysts' monthly abnormal forecast revisions for months -6 to -1 . 


\section{(ii) Estimation of unexpected provisions}

An inventory of reported provisions during 1989 to 1997 indicates that Dutch companies report three different categories of provisions on a regular basis. These categories are: (1) provisions for warranty costs (30\% of the examined financial statements), (2) provisions for underinsured property (20.2\%), and (3) provisions for maintenance costs (16.7\%). Furthermore, $64.2 \%$ of the examined companies report non-specified 'other' provisions, which are likely to consist of one or more of the above provisions. These four categories of provisions are central to this investigation.

In order to estimate the unexpected component of reported changes in provisions, I assume that investors and financial analysts associate each type of provision with a specific item in the annual financial statements. I predict changes in provisions for warranty costs as a function of the change in sales; changes in provisions for underinsured property as a function of the change in gross property, plant and equipment; and changes in provisions for maintenance costs as a function of the change in accumulated depreciation. The residuals of these regressions equal the unexpected changes in the respective provisions.

The central idea underlying the estimation of unexpected changes in other provisions is that these provisions likely consist of provisions for warranty costs, provisions for underinsured property or provisions for maintenance costs, if these provisions are not reported separately. Hence, I predict changes in other provisions as a function of the change in sales, the change in gross property, plant and equipment and the change in accumulated depreciation. However, I set the value of these variables equal to zero if the provision that is associated with this variable is reported separately in the financial statements. That is, unexpected other provisions equal 
the residuals of the following regression:

$$
\mathrm{OP}_{\mathrm{it}}=\beta_{0}+\beta_{1} \mathrm{D}_{1} \Delta \mathrm{S}_{\mathrm{it}}+\beta_{2} \mathrm{D}_{2} \Delta \mathrm{PPE}_{\mathrm{it}}+\beta_{3} \mathrm{D}_{3} \Delta \mathrm{ACCDEP}_{\mathrm{it}}+\epsilon_{\mathrm{it}}
$$

in which $\mathrm{OP}_{\mathrm{it}}$ denotes changes in total other provisions, $\Delta \mathrm{S}_{\mathrm{it}}$ equals the change in sales, $\triangle \mathrm{PPE}_{\mathrm{it}}$ equals the change in gross property, plant and equipment and $\triangle \mathrm{ACCDEP}_{\text {it }}$ equals the change in accumulated depreciation. $\mathrm{D}_{1}, \mathrm{D}_{2}$ and $\mathrm{D}_{3}$ are indicator variables that equal one if the financial statements do not contain separate disclosures of provisions for warranty costs, provisions for underinsured property and provisions for maintenance costs respectively. The residual, $\epsilon_{\mathrm{it}}$, represents my estimate of unexpected changes in other provisions. ${ }^{9}$ Table 2 presents the estimated coefficients of the regression analysis. In order to size-adjust changes in provisions, I estimate all unexpected changes in provisions by using Generalized Least Squares regressions where I weight the dependent and independent variables with lagged total assets.

[Table 2 about here.]

In the sample used throughout this study the mean absolute value of the estimated unexpected changes in provisions equals $18.6 \%$ of earnings before provisions (median $4.2 \%$ ). Hence, this set of (largely) discretionary accruals is clearly identifiable, but also large enough to matter, which is a necessary condition for a potentially successful account-specific approach (see Schipper 1989).

\section{(iii) Information asymmetry}

Previous research has produced many proxies for the degree of information asymmetry between managers and common shareholders, since actual information asymmetry is not measurable. This study considers a set of five of these proxy variables and uses factor analysis to 
extract the common variance and construct factors scores. The variables reflecting the degree of information asymmetry are:

1. Level of analyst following: This variable equals the number of analysts that submitted to $\mathrm{I} / \mathrm{B} / \mathrm{E} / \mathrm{S}$ one or more earnings forecasts. I expect that the level of analyst following is negatively correlated with the degree of information asymmetry, since the number of informed traders increases with analysts following (see e.g. Brennan and Subrahmanyam 1995);

2. Financial analysts' consensus forecast error: I measure the consensus forecast error as the absolute difference between actual earnings and the mean of the last earnings forecasts that analysts submitted. Barron et al. (1998) indicate that the consensus forecast error reflects the error in (analysts' interpretation of) publicly available information, i.e. common error, and part of the error in analysts' private information, i.e. idiosyncratic error, that is not completely eliminated by combining individual forecasts when the number of available forecasts is small. I expect analysts' consensus forecast error to be positively correlated with the degree of information asymmetry;

3. Financial analysts' forecast dispersion: Forecast dispersion equals the standard deviation of the last earnings forecasts that analysts submitted. This variable reflects the idiosyncratic noise in analysts' private information. I expect analysts' forecast dispersion to be positively correlated with the degree of information asymmetry;

4. Volatility of abnormal stock returns during the estimation period: This variable equals the standard deviation of daily stock returns during the estimation period;

5. Volatility of abnormal stock returns during the event period: This variable equals the 
standard deviation of daily stock returns during the event period. My expectations are that the volatility of abnormal stock returns during the estimation period and during the announcement period are positively correlated with the level of information asymmetry (see e.g. Krishnaswami and Subramaniam 1999).

The rationale for using factor analysis is that each of the above variables is a noisy measure of the degree of information asymmetry. Factor analysis determines the variance in each variable that is shared with the other variables and eliminates variance that is uniquely related to one variable from the information asymmetry measure. ${ }^{10}$ In a confirmatory factor analysis, the estimated loadings of the above five items have the expected sign and are significant at the 0.01 alpha level.

\section{EMPIRICAL RESULTS}

\section{(i) Descriptive statistics}

Table 3 shows descriptive statistics of firm size, information asymmetry, stock ownership and provisions for structure and non-structure companies. It appears from these statistics that the examined non-structure companies are larger on average than structure companies in terms of total assets $(12,745$ versus 1,363$)$ and net sales $(15,723$ versus 1,951). Furthermore, the average values of the information asymmetry measure, the fraction of common shares outstanding held by the largest blockholder and the fraction of shares outstanding held by the CEO, indicate that non-structure companies have lower information asymmetry on average than structure companies $(-0.1588$ versus 0.0264$)$, higher concentration of stock ownership $(0.2626$ versus 0.2026$)$ and CEOs owning a larger fraction of common shares outstanding $(0.0805$ versus 0.0088). ${ }^{11}$ Ignoring differences in board effectiveness, these differences in the degree 
of information asymmetry and concentrated stock ownership would imply that especially management of structure companies uses provisions to communicate with shareholders, given that the level of informative provision management increases as a function of information asymmetry, as argued in the previous section, and decreases as a function of the degree of supervision by shareholders. This would be contrary to my prediction.

[Table 3 about here.]

The average level of provisions, defined as the sum of provisions for warranty costs, provisions for underinsured property, provisions for maintenance costs and 'other' provisions, scaled by lagged total assets, is not significantly different between structure companies and non-structure companies. This suggests that these provisions are equally important to both types of companies. Unexpected changes in provisions, scaled by lagged total assets, are higher on average for structure companies than for non-structure companies (0.0005 versus -0.0001). This is consistent with the idea that structure companies report more conservatively than non-structure companies, recognizing unexpected increases in provisions but not recognizing unexpected decreases in provisions, since structure companies have more effective supervision.

\section{(ii) Univariate analysis}

Panel A of table 4 shows the abnormal stock returns and abnormal forecast revisions surrounding the announcement of unexpected changes provisions. ${ }^{12}$ I split the sample according to the sign of these changes, removing 85 firm-year observations with zero unexpected changes. The results indicate that on days 0 and +1 abnormal stock returns are higher when provisions increase unexpectedly than when provisions decrease unexpectedly. The difference is 
moderately significant on day $0(\mathrm{t}=1.94, \mathrm{p}<0.10)$. The stock market reaction on the first trading day after the announcement date, i.e. day +1 , is also relevant as some of the companies included in the sample announced their annual results after the exchange closing hours. The cumulative abnormal stock return for day 0 to +1 , reported in panel $\mathrm{B}$ of table 4 , is significantly higher at the alpha 0.05 level when provisions increase unexpectedly than when they decrease unexpectedly (difference $0.8107, \mathrm{t}=2.33$ ). This is consistent with the idea that unexpected increases in provisions are used to signal 'good' future performance.

Consistent with the stock market reaction, analysts' abnormal forecast revisions, reported in panel $\mathrm{C}$ of table 4, are higher when provisions increase unexpectedly. The differences are not significant and the greatest when revisions are measured over a four-month period starting in month 0 (difference $0.6591, \mathrm{t}=1.43$ ). This may indicate that either in the months after the announcement month analysts receive and incorporate information that confirms the information reflected by the unexpected changes in provisions or some forecast revisions in the announcement month are not based on the information reflected by the unexpected changes in provisions. The latter explanation implies that submission dates reported by I/B/E/S may not correspond to analysts' actual revision date. In order to allow for this possibility but to minimize the influence of information disclosed after the announcement month, I use forecast revisions for month 0 to +1 in the revision regressions that are discussed in the next section.

[Table 4 about here.]

In order to investigate whether analysts and investors (1) anticipate the unexpected changes in provisions, or (2) underreact to the announcement and correct for the underreaction in the post-event period, I report abnormal stock returns and abnormal forecast revisions during the pre-event period and post-event period in table 5. The results indicate that analysts may anticipate unexpected changes in provisions during the months -6 to -4 . 
The difference in abnormal forecast revisions equals $0.4433(\mathrm{t}=1.82, \mathrm{p}<0.10)$. There is no indication that abnormal stock returns are significantly different during the pre-event period or the post-event period.

[Table 5 about here.]

\section{(iii) Multivariate analysis}

Table 6 reports the estimated coefficients of regression equation (1), where the dependent variables equal the cumulative abnormal stock returns for day 0 to +1 and analysts' forecast revisions for month 0 to +1 . Column SC (NSC) shows the coefficients of the sample consisting of structure companies (non-structure companies). Column NSC-SC shows the differences between coefficients reported in columns NSC and SC. ${ }^{13}$

[Table 6 about here.]

The results reported in table 6 confirm hypothesis 1 , that abnormal stock returns and analysts' abnormal forecast revisions are less correlated with unexpected changes in provisions of structure companies than with unexpected changes in provisions of non-structure companies, and hypothesis 2 , that the market reaction to unexpected changes in provisions of structure companies is more pronounced when the degree of information asymmetry between management and shareholders increases. The parameter estimates of the return regressions indicate that unexpected increases in provisions cause a positive share price reaction, both for structure companies and non-structure companies $(\mathrm{t}=2.27, \mathrm{p}<0.05$ and $\mathrm{t}=3.11, \mathrm{p}<0.01$ respectively). The difference between the coefficients on unexpected changes in provisions of both companies is significant at the 0.05 alpha level. This suggests that the fact that supervisors of structure companies exercise more effective discipline over company management, 
results in the situation where these companies use provisions to a lesser extent for the purpose of signalling. This is consistent with hypothesis 1 .

The coefficient on INFOASYM $\mathrm{it}_{\mathrm{it}} \mathrm{UP}_{\text {it }}$ significantly positive at the 0.01 alpha level for nonstructure companies $(\mathrm{t}=3.26)$. This means that the market reaction is more pronounced when the degree of information asymmetry increases, as hypothesis 2 predicted. The significantly positive difference between the coefficients of the two different types of firms $(\mathrm{t}=2.29, \mathrm{p}<0.05)$ confirms that the incentive to signal is especially present for managers of non-structure companies with a high degree of information asymmetry, as argued in the previous section.

The results of the revision regressions are consistent with the results of the return regressions. The coefficient on $\mathrm{UP}_{\text {it }}$ is significantly positive for both type of companies $(\mathrm{t}=2.07$, $\mathrm{p}<0.05$ for structure companies; $\mathrm{t}=2.62, \mathrm{p}<0.01$ for non-structure companies). The difference between both types is positive and significant at the 0.05 alpha level. The coefficient on INFOASYM $_{i t} U_{i t}$ is significantly higher for non-structure companies $(t=1.79, p<0.10)$. In sum, the empirical results suggest that management uses unexpected changes in provisions to signal 'good news'. However, effective discipline exercised by the powerful Supervisory Board of structure companies restrains this type of informative provision management. The market reaction to unexpected changes in provisions of non-structure companies increases with the degree of information asymmetry.

\section{(iv) Sensitivity analysis}

Alternative governance variables

The previous analysis focused on governance structures that are typical for companies listed on the Dutch stock exchange. The underlying assumption is that the disciplinary power of 
Dutch shareholders is low, which calls for a functional Supervisory Board. However, two situations can arise in which the difference between structure companies and non-structure companies disappears. This may result in an underestimation of the effect of the structure law. First, the members of the Supervisory Board and the members of the Executive Board may collude. In such a case the disciplinary power of the Supervisory Board of a structure company is probably not significantly higher than the disciplinary power of the common shareholders of non-structure companies. Collusion of supervisors and managers of structure companies therefore reduces differences in board effectiveness. A similar situation may arise when a manager of a structure company owns a large fraction of the company's shares, increasing management's power. Second, shareholders of companies exempt from the structure law may seek for alternative disciplinary mechanisms, such as ownership concentration, and consequently reduce the differences in monitoring quality between their companies and structure companies.

To examine the effect of three alternative governance variables, I estimate the following equation:

$$
\begin{aligned}
\operatorname{AR}_{i t}= & \gamma_{0}+\gamma_{1} \Delta \mathrm{E}_{\mathrm{it}}+\gamma_{2} \mathrm{UP}_{\mathrm{it}}+\gamma_{3} \mathrm{INFOASYM}_{\mathrm{it}}+\gamma_{4} \mathrm{INFOASYM}_{\mathrm{it}} \mathrm{UP}_{\mathrm{it}}+ \\
& \gamma_{5} \text { OUTBLOCK }_{\mathrm{it}} \mathrm{UP}_{\mathrm{it}}+\gamma_{6} \text { MANBLOCK }_{\mathrm{it}} \mathrm{UP}_{\mathrm{it}}+ \\
& { }_{7} \text { SUPEXEC }_{\mathrm{it}} \mathrm{UP}_{\mathrm{it}}+\eta_{\mathrm{it}}
\end{aligned}
$$

in which OUTBLOCK $_{i t}$, a proxy for ownership concentration, denotes the percentage of common shares outstanding held by the largest outside blockholder, MANBLOCK it $_{\text {denotes }}$ the percentage of common shares outstanding held by the CEO, if he is the largest blockholder, $\mathrm{SUPEXEC}_{\mathrm{it}}$, a proxy for the chance of collusion, equals the ratio of the number of supervisors 
and the number of executives, and the remaining variables are as defined in the previous sections. In a second regression I replace $\mathrm{AR}_{\mathrm{it}}$ with $\mathrm{UREV}_{\mathrm{it}}$.

[Table 7 about here.]

Table 7 shows the results of the regression analysis. The abnormal return regression yields coefficients on OUTBLOCK $\mathrm{it}_{\mathrm{it}}$ and MANBLOCK $\mathrm{UP}_{\mathrm{it}} \mathrm{UP}_{\text {it }}$ that are only statistically significant for non-structure companies $(\mathrm{t}=-2.14, \mathrm{p}<0.05$ and $\mathrm{t}=1.70, \mathrm{p}<0.10$, respectively). The abnormal revision regression yields a statistically significant difference between coefficients of structure companies and non-structure companies on $\mathrm{OUTBLOCK}_{\mathrm{it}} \mathrm{UP}_{\mathrm{it}}(\mathrm{t}=-2.13, \mathrm{p}, 0.05)$. This emphasizes that shareholders of structure companies have low disciplinary power since some important authorities devolved to the Supervisory Board, reducing the influence of stock ownership concentration and management's voting power. The results weakly indicate that increased ownership concentration of non-structure companies can reduce the differences in informative provision management between structure companies and non-structure companies. Coefficients on UP and INFOASYM $\mathrm{it}_{\mathrm{it}} \mathrm{UP}_{\mathrm{it}}$ for structure companies remain significantly different from those for non-structure companies and the differences appear to be slightly more significant than those reported in table 6 (regression equation without the alternative governance variables). These results are consistent with my expectation that shareholders of non-structure companies reduce monitoring problems by means of alternative disciplinary mechanisms, as argued above. The ratio of the number of supervisors and the number of executives, which proxies for the chance of collusion, is insignificant for all samples.

\section{Alternative return and revisions intervals}

Dependent variables in the regression analyses discussed in the previous section were the cumulative abnormal stock return for day 0 to +1 and analysts' abnormal forecast revisions 
for month 0 to +1 . I also considered different return and revision intervals to assess the sensitivity of the parameter estimates to the choice for a specific interval. Table 8 reports the differences between parameter estimates of structure companies and estimates of nonstructure companies. The results for the five-days return interval (days -2 to +2 ) and threedays return interval (days -1 to +1 ) are qualitatively similar to the results presented in table 6 . However, it appears from these estimates that the significance of differences between structure companies and non-structure companies decreases when the length of the return interval increases.

When abnormal forecast revisions in month 0 are the dependent variable, the results are also qualitatively similar to the results reported in table 6 . Using abnormal forecast revisions for the months 0 to +3 as the dependent variable results in insignificant differences between structure companies and non-structure companies. These forecast revisions probably impound large amounts of other information than the information that is released on the announcement date.

[Table 8 about here.]

Firm size

The descriptive statistics indicate that non-structure companies are larger than structure companies on average. In order to investigate whether firm size drives the empirical results, I split my sample into two subsamples with equal numbers of observations according to the level of my proxy for information asymmetry and estimate the following regression equation:

$$
\mathrm{AR}_{\mathrm{it}}=\delta_{0}+\delta_{1} \Delta \mathrm{E}_{\mathrm{it}}+\delta_{2} \mathrm{UP}_{\mathrm{it}}+\delta_{3} \mathrm{STRUCTURE}_{\mathrm{it}}+\delta_{4} \mathrm{STRUCTURE}_{\mathrm{it}} \mathrm{UP}_{\mathrm{it}}+
$$




$$
\delta_{5} \mathrm{SIZE}_{\mathrm{it}}+\delta_{6} \mathrm{SIZE}_{\mathrm{it}} \mathrm{UP}_{\mathrm{it}}+v_{\mathrm{it}}
$$

in which STRUCTURE $E_{i t}$ is an indicator variable that equals one if the company is a structure company, $\mathrm{SIZE}_{\mathrm{it}}$ denotes the natural logarithm of net sales, and the remaining variables are as defined in the previous sections. In a second regression I replace $A_{i t}$ with $U R E V_{i t}$.

The high information asymmetry subsample contains 51 observations of non-structure companies. This equals $39.8 \%$ of the total set of observations of non-structure companies. In this high information asymmetry subsample, the coefficient on $\mathrm{STRUCTURE}_{\mathrm{it}} \mathrm{UP}_{\mathrm{it}}$ equals $-1.3487(\mathrm{t}=-2.19, \mathrm{p}<0.05)$ when abnormal stock returns are the dependent variable and $-2.3413(\mathrm{t}=-7.39, \mathrm{p}<0.01)$ when abnormal forecast revisions are the dependent variable. The coefficient on STRUCTURE $\mathrm{it}_{\mathrm{it}} \mathrm{UP}_{\text {it }}$ is not significantly different from zero in the low information asymmetry subsample. The coefficient on $\mathrm{SIZE}_{\mathrm{it}} \mathrm{UP}_{\mathrm{it}}$ is not significant in all regressions.

These results indicate that firm size does not drive the empirical results. The significant coefficients on STRUCTURE $\mathrm{it}_{\mathrm{it}} \mathrm{UP}_{\mathrm{it}}$ in the high information asymmetry subsample are consistent with the above results, that structure companies have less opportunity than nonstructure companies to engage in signalling when the degree of information asymmetry is high.

\section{Conclusions}

This paper addresses the influence of corporate structure on the informativeness of reported unexpected changes in provisions. It contributes to the earnings management literature by focusing on governance structures and management's discretion in financial reporting in a non-US market. The governance structures in the Netherlands provide a unique research op- 
portunity, since two corporate systems with considerable differences in supervision coexist in one market. The Dutch reported provisions that I analyse include provisions for maintenance costs, provisions for underinsured property, which are both highly discretionary and not allowed under International Accounting Standards and US GAAP, and non-specified 'other' provisions.

I compare structure companies, where the Supervisory Board can exercise effective discipline over company management, with non-structure companies, where supervisors' disciplinary power is low. The empirical evidence indicates that financial analysts and investors interpret unexpected increases (decreases) in provisions as 'good' news ('bad' news) about future performance, if the company is a non-structure company. The market reaction to unexpected changes in provisions of non-structure companies is more pronounced when my estimate of information asymmetry between management and shareholders is high. Supervisors of structure companies effectively restrain this type of provision management, reducing the informativeness of unexpected changes in provisions. The empirical results are therefore consistent with the idea that management uses its discretion in reporting unexpected provisions for the purpose of signalling future performance and reducing the degree of information asymmetry. However, increases in the disciplinary power of the Supervisory Board reduce management's discretion and the information usefulness of reported provisions.

The empirical results add to the evidence of Subramanyam (1996), Bartov and Bodnar (1996) and Beatty and Harris (1998), indicating that management may not necessarily use its discretion opportunistically. Furthermore, given that previous research indicates that Dutch financial reporting is relatively informative, the results raise an interesting question. Are the observed differences in informativeness between Dutch companies and non-Dutch companies attributable to accounting decisions of structure companies or non-structure companies? The 
results highlight an important limitation of international comparisons of the value relevance of accounting data focusing on international differences in financial accounting and auditing regulation. They indicate that international and national differences in corporate structure can strongly influence the informativeness of financial reporting. This is an area for future research.

\section{Notes}

${ }^{1}$ Mueller et al. (1994) identify five accounting clusters based on international accounting similarities. They characterize the Dutch approach as British-American and indicate that the British-American accounting cluster should really be called the British-North American-Dutch cluster.

${ }^{2}$ Frantz (1999) proves analytically that a manager whose firm is about to restructure and whose bonus depends on both firm value and accounting earnings, is induced to signal his private information about the firm's future profitability by means of a restructuring provision. When current earnings exceed the lower bound of the manager's bonus plan prior to the restructuring, recognizing the restructuring costs will maximize the manager's compensation only if the restructuring action is likely to increase future earnings. In such a case the recognition of a restructuring provision, signalling 'good news', will increase current firm value, and advancing the recognition of restructuring expenses will safeguard future earnings-based compensation. Furthermore, Frantz shows that in this situation the share price reaction is a strictly increasing linear function of the size of the restructuring provision.

${ }^{3}$ One could argue that shareholder-oriented supervisors should favor conservative reporting (see e.g. Ball et al. 2000). This would reduce the informativeness of unexpected changes in provisions of non-structure companies (if the supervisors have the necessary disciplinary power) and be contrary to my prediction.

${ }^{4}$ In practice, devolving the authority to make amendments to the annual statements to the Supervisory Board is not likely to put large restrictions on management's discretion. The Management Board is probably better informed about true performance than the Supervisory Board. However, when supervisors and managers disagree on the contents of the annual statements, such as accounting procedures or provisions, supervisors of structure companies should have more influence on the outcomes of such a conflict than supervisors on non-structure companies. On the other hand, supervisors of non-structure companies retain the formal right not to approve the annual statements.

${ }^{5}$ For an inventory of these takeover defences, see Kabir et al. (1997)

${ }^{6}$ The degree of information asymmetry may be negatively associated with unexpected changes in 
provisions, if managers of structure companies have stronger incentive to smooth reported earnings by means of provisions in order to avoid reporting low earnings that could have resulted in dismissal, as suggested by DeFond and Park (1997). This is possible when the probability that managers are dismissed based on 'poor' earnings performance depends on the availability of alternative indicators of future performance. If the Supervisory Board accesses little alternative information, it is likely to base its judgment on readily available earnings figures. This would induce managers of companies subject to the structure law to smooth reported earnings when the degree of information asymmetry is high. An implicit assumption is that the measured degree of information asymmetry between management and shareholders proxies for the degree of information asymmetry between management and Supervisory Board.

${ }^{7}$ Forecast submission dates in my sample reflect analysts' tendency to revise their forecasts every five months on average.

${ }^{8}$ I define the daily market return as the daily percentage change in total market capitalization of the Amsterdam Stock Exchange.

${ }^{9}$ Decreases in provisions could also be associated with the use of provisions as a result of cash outflows. For instance, an unexpected decrease in the provision for major maintenance could indicate that the company started to carry out major maintenance work. This could add noise to the measure of unexpected changes in provisions. However, since this applies to the provisions of all observed companies, I do not expect that this will systematically affect the empirical results.

${ }^{10}$ Including the last variable (volatility of abnormal stock returns during the event period) in my information asymmetry measure may create spurious correlation. The greater the level of abnormal stock return, the greater the measured volatility is likely to be. However, including the information asymmetry measure as an independent variable in the regressions, should correct for this and insure that the interaction term INFOASYM $\mathrm{it}_{\mathrm{it}} \mathrm{UP}_{\mathrm{it}}$ in regression equation 1 is not correlated with the dependent variable by construction. Furthermore, results of the regression analysis, which are reported in the next section, indicate that the information asymmetry measure is not significantly correlated with abnormal stock returns.

${ }^{11}$ I define the outside blockholder variable as the fraction of common shares outstanding that is owned by the largest blockholder (not being management). Dutch legislation requires shareholders to disclose the percentage of common shares outstanding that they own only if this percentage exceeds five percent. In this study this percentage is assumed to be zero when no disclosure has taken place. I define the management blockholder variable as the fraction of common shares outstanding that is owned by the CEO is he is the largest blockholder.

${ }^{12}$ In the univariate analysis, I also weight abnormal stock returns with the (firm-year-specific) standard deviation of the daily abnormal returns during the estimation period and abnormal forecast 
revisions with the (firm-year-specific) standard deviation of analysts' monthly abnormal forecast revisions for months -6 to -1 , in order to adjust for differences in unsystematic risk and differences in the heterogeneity of analysts' interpretations.

${ }^{13} \mathrm{I}$ calculate the t-statistics of differences between parameters $\beta_{\mathrm{i}}^{\text {nsc }}$ of model $n s c$ and parameters $\beta_{i}^{s c}$ of model $s c$ as follows:

$$
\mathrm{t}_{\mathrm{i}}^{\mathrm{diff}}=\frac{\beta_{\mathrm{i}}^{\text {nsc }}-\beta_{\mathrm{i}}^{\mathrm{sc}}}{\left[\operatorname{Var}\left(\epsilon^{\mathrm{all}}\right)\right]^{0.5}\left[\operatorname{Var}\left(\mathrm{b}_{\mathrm{i}}^{\mathrm{nsc}}\right) / \operatorname{Var}\left(\epsilon^{\mathrm{nsc}}\right)+\operatorname{Var}\left(\mathrm{b}_{\mathrm{i}}^{\mathrm{sc}}\right) / \operatorname{Var}\left(\epsilon^{\mathrm{sc}}\right)\right]^{0.5}}
$$

in which:

$$
\operatorname{Var}\left(\epsilon^{\mathrm{all}}\right)=\frac{\left(\mathrm{n}^{\mathrm{nsc}}-\mathrm{k}^{\mathrm{nsc}}-1\right) \operatorname{Var}\left(\epsilon^{\mathrm{nsc}}\right)+\left(\mathrm{n}^{\mathrm{sc}}-\mathrm{k}^{\mathrm{sc}}-1\right) \operatorname{Var}\left(\epsilon^{\mathrm{sc}}\right)}{\mathrm{n}^{\mathrm{nsc}}+\mathrm{n}^{\mathrm{sc}}-\mathrm{k}^{\mathrm{nsc}}-\mathrm{k}^{\mathrm{sc}}-2}
$$

and $\operatorname{Var}\left(b_{i}^{\text {nsc }}\right)$ denotes the estimated variance of parameter estimate $b_{i}^{\text {nsc }}, \operatorname{Var}\left(\epsilon^{\text {nsc }}\right)$ denotes the mean squared error of model $n s c, n^{n s c}$ equals the number of observations used to estimate model $n s c$ and $k^{n s c}$ equals the number of estimated parameters of model $n s c$.

\section{REFERENCES}

Alford, A., J. Jones, R. Leftwich and M. Zmijewski (1993), 'The Relative Informativeness of Accounting Disclosures in Different Countries', Journal of Accounting Research, Vol. 31 , pp. 183-223.

Ball, R., S. P. Kothari and A. Robin (2000), 'The Effect of International Institutional Factors on Properties of Accounting Earnings', Journal of Accounting and Economics, Vol. 29 , pp. $1-51$.

Barron, O. E., O. Kim, S. C. Lim and D. E. Stevens (1998), 'Using Analysts' Forecasts to Measure Properties of Analysts' Information Environment', The Accounting Review, Vol. 73 (October), pp. 421-433.

Bartov, E., F. W. Lindahl and W. E. Ricks (1998), 'Stock Price Behavior Around Announcements of Write-Offs', Review of Accounting Studies, Vol. 3, pp. 327-346.

Bartov, E. and G. M. Bodnar (1996), 'Alternative Accounting Methods, Information Asymmetry and Liquidity: Theory and Evidence', The Accounting Review, Vol. 71 (July), pp. 397-418.

Basu, S., L. Hwang and C.-L. Jan (1998), 'International Variation in Accounting Measurement Rules and Analysts' Earnings Forecast Errors', Journal of Business Finance 83 Accounting, Vol. 25, pp. 1207-1247.

Beasley, M. S. (1996), 'An Empirical Analysis of the Relation Between the Board of Director Composition and Financial Statement Fraud', The Accounting Review, Vol. 71 (October), pp. $443-465$. 
Beatty, A. and D. G. Harris (1998), 'The Effects of Taxes, Agency Costs and Information Asymmetry on Earnings Management: A Comparison of Public and Private Firms', Review of Accounting Studies, Vol. 3, pp. 299-326.

Brennan, M. J. and A. Subrahmanyam (1995), 'Investment Analysis and Price Formation in Securities Markets', Journal of Financial Economics, Vol. 38, pp. 361-381.

Brickley, J. A. and L. D. Van Drunen (1990), 'Internal Corporate Restructuring: An Empirical Analysis', Journal of Accounting and Economics, Vol. 12, pp. 251-280.

Brous, P. A. and O. Kini (1993), 'A Reexamination of Analysts' Earnings Forecasts for Takeover Targets', Journal of Financial Economics, Vol. 33 (April), pp. 201-225.

Bunsis, H. (1997), 'A description and market analysis of write-off announcements', Journal of Business Finance 65 Accounting, Vol. 24 (October/December), pp. 1385-1400.

Burgstahler, D. and I. Dichev (1997), 'Earnings Management to Avoid Earnings Decreases and Losses', Journal of Accounting and Economics, Vol. 24, pp. 99-126.

Capstaff, J., K. Paudyal and W. Rees (1996), 'A Comparitive Analysis of Earnings Forecasts in Europe'Working Paper, University of Glasgow.

Chaney, P. K., C. E. Hogan and D. C. Jeter (1999), 'The effect of reporting restructuring charges on analysts' forecast revisions and errors', Journal of Accounting and Economics, Vol. 27, pp. 261-284.

Dechow, P. M., R. G. Sloan and A. P. Sweeney (1996), 'Causes and Consequences of Earnings Manipulation: An Analysis of Firms Subject to Enforcement Actions by the SEC', Contemporary Accounting Research, Vol. 13 (Spring), pp. 1-36.

DeFond, M. L. and C. W. Park (1997), 'Smoothing Income in Anticipation of Future Earnings', Journal of Accounting and Economics, Vol. 23, pp. 115-139.

DeFond, M. L. and J. Jiambalvo (1994), 'Debt Covenant Violation and Manipulation of Accruals', Journal of Accounting and Economics, Vol. 17, pp. 145-176.

Degeorge, F., J. Patel and R. Zeckhauser (1998), 'Earnings Management to Exceed Thresholds'Discussion Paper, Centre for Economic Policy Research.

Frantz, P. (1999), 'Discretionary Write-Downs, Write-Offs, and Other Restructuring Provisions: A Signalling Approach', Accounting and Business Research, Vol. 29, pp. 109-121.

Fudenberg, D. and J. Tirole (1995), 'A Theory of Income and Dividend Smoothing Based on Incumbency Rents', Journal of Political Economy, Vol. 103, pp. 75-93.

Healy, P. M. (1985), 'The Effect of Bonus Schemes on Accounting Decisions', Journal of Accounting and Economics, Vol. 7, pp. 85-107.

Healy, P. M. and K. G. Palepu (1993), 'The Effect of Firms' Financial Disclosure Strategies on Stock Prices', Accounting Horizons, Vol. 7 (March), pp. 1-11.

Holthausen, R. W., D. F. Larcker and R. G. Sloan (1995), 'Annual Bonus Schemes and the Manipulation of Earnings', Journal of Accounting and Economics, Vol. 19, pp. 29-74. 
Holthausen, R. W. and R. E. Verrecchia (1988), 'The Effect of Sequential Information Releases on the Variance of Price Changes in an Intertemporal Multi-Asset Market', Journal of Accounting Research, Vol. 26 (Spring), pp. 82-106.

Jones, J. J. (1991), 'Earnings Management During Import Relief Investigations', Journal of Accounting Research, Vol. 29, pp. 193-228.

Kabir, R., D. Cantrijn and A. Jeunink (1997), 'Takeover Defenses, Ownership Structure and Stock Returns in the Netherlands: An Empirical Analysis', Strategic Management Journal, Vol. 18, pp. 97-109.

Krishnaswami, S. and V. Subramaniam (1999), 'Information Asymmetry, Valuation, and the Corporate Spin-Off Decision', Journal of Financial Economics, Vol. 53, pp. 73-112.

Lev, B. and S. Kunitzky (1974), 'On the Association Between Smoothing Measures and the Risks of Common Stocks', The Accounting Review, Vol. 49, pp. 259-270.

Mueller, G. G., H. Gernon and G. Meek (1994), Accounting: An International Perspective (Business One Irwin, New York, N.Y.).

Peasnell, K. V., P. F. Pope and S. Young (1998), 'Outside Directors, Board Effectiveness, and Earnings Management'Working Paper, Lancaster University.

Roe, M. J. (1994), Strong Managers, Weak Owners: The Political Roots of American Corporate Finance (Princeton University Press, Princeton, N.J.).

Schipper, K. (1989), 'Commentary on Earnings Management', Accounting Horizons, Vol. 3, pp. 91-102.

Shleifer, A. and R. W. Vishny (1997), 'A Survey of Corporate Governance', The Journal of Finance, Vol. 52 (June), pp. 737-783.

Subramanyam, K. R. (1996), 'The Pricing of Discretionary Accruals', Journal of Accounting and Economics, Vol. 22, pp. 249-281.

Sweeney, A. P. (1994), 'Debt-Covenant Violations and Managers' Accounting Responses', Journal of Accounting and Economics, Vol. 17, pp. 281-308.

Teoh, S. H. and C. Y. Hwang (1991), 'Nondisclosure and Adverse Disclosure as Signals of Firm Value', The Review of Financial Studies, Vol. 4, pp. 283-313.

Trueman, B. and S. Titman (1988), 'An Explanation for Accounting Income Smoothing', Journal of Accounting Research, Vol. 26, pp. 127-143.

Wahlen, J. M. (1994), 'The nature of information in commercial bank loan loss disclosures', The Accounting Review, Vol. 69 (July), pp. 455-478.

Warfield, T. D., J. J. Wild and K. L. Wild (1995), 'Managerial Ownership, Accounting Choices, and Informativeness of Earnings', Journal of Accounting and Economics, Vol. 20, pp. 61-91.

Warther, V. A. (1998), 'Board Effectiveness and Board Dissent: A Model of the Board's Relationship to Management and Shareholders', Journal of Corporate Finance, Vol. 4, pp. 5370 . 
Table 1:

Characteristics of corporate structures and the effectiveness of Supervisory Boards in the Netherlands

\begin{tabular}{|c|c|c|c|c|}
\hline Category & Regime & Authorities & Appointment & Board effectiveness \\
\hline $\begin{array}{l}\text { Structure } \\
\text { companies }\end{array}$ & Structure & $\begin{array}{l}\text { - Dismiss management } \\
\text { - Amend annual report } \\
\text { - Veto strategic decisions }\end{array}$ & Co-optation & High \\
\hline
\end{tabular}

\begin{tabular}{|c|c|c|c|}
\hline \multirow[t]{3}{*}{$\begin{array}{l}\text { Non-structure } \\
\text { companies }\end{array}$} & $\begin{array}{l}\text { Mitigated } \\
\text { structure }\end{array}$ & - Veto strategic decisions & Co-optation \\
\hline & Exempted & - & $\begin{array}{l}\text { Shareholders' } \\
\text { Meeting }^{\mathrm{a}}\end{array}$ \\
\hline & Common & - & $\begin{array}{l}\text { Shareholders' } \\
\text { Meeting }^{\mathrm{a}}\end{array}$ \\
\hline
\end{tabular}

\footnotetext{
a Members of the Supervisory Board of these companies are elected at the General Shareholders' Meeting. However, the bylaws of these companies may prescribe that one third of the Supervisory Board is elected by others than the company's shareholders.
} 
Table 2:

Generalized Least Squares estimation of unexpected changes in provisions

\begin{tabular}{lcccccr}
\hline \multicolumn{1}{c}{ Dependent variable } & Intercept & $\Delta S$ & $\Delta P P E$ & $\Delta A C C D E P$ & F-value & adjusted $R^{2}$ \\
\hline $\begin{array}{l}\text { Provision for warranty } \\
\text { costs (N=243) }\end{array}$ & $\begin{array}{c}-18.0231 \\
(-0.50)\end{array}$ & 0.0074 & & & $38.55^{\dagger}$ & $13.43 \%$ \\
& & & & & & \\
Provision for & 33.3630 & & 0.0051 & & $12.15^{\dagger}$ & $6.40 \%$ \\
underinsured property & $(1.20)$ & & $(3.49)^{\dagger}$ & & & \\
(N=164) & & & & & & \\
Provision for & 10.0646 & & & 0.0097 & $4.05^{\dagger}$ & $2.23 \%$ \\
maintenance costs & $(0.34)$ & & & $(2.01)^{\ddagger}$ & & \\
(N=135) & & & & & \\
Other provisions & 112.4134 & 0.0057 & 0.0034 & 0.0173 & $7.71^{\dagger}$ & $3.73 \%$ \\
(N=520) & $(1.77)^{*}$ & $(2.49)^{\ddagger}$ & $(0.54)$ & $(1.63)$ & & \\
\hline
\end{tabular}

Notes:

Unexpected changes in provisions are estimated using Generalized Least Squares regressions, where I weight the dependent and independent variables with lagged total assets. The independent variables have the following definitions:
$\triangle S=$
Annual change in net sales
$\triangle P P E=$
Annual change in gross property, plant and equipment
$\triangle A C C D E P=$ Annual change in accumulated depreciation

$\dagger, \ddagger, *$ Significant at the two-tailed $0.01,0.05$ and 0.10 alpha level, respectively. 
Table 3:

Descriptive statistics of size, information asymmetry, stock ownership and provisions

\begin{tabular}{|c|c|c|c|c|c|}
\hline Variables & Mean & $\begin{array}{c}\text { Standard } \\
\text { Deviation }\end{array}$ & $\begin{array}{c}\text { Lower } \\
\text { Quartile }\end{array}$ & Median & $\begin{array}{c}\text { Upper } \\
\text { Quartile }\end{array}$ \\
\hline \multicolumn{6}{|c|}{ Panel A: Non-structure companies $(\mathrm{N}=128)$} \\
\hline Total assets & 12,745 & 20,756 & 594 & 1,818 & 12,119 \\
\hline Net sales & 15,723 & 25,435 & 852 & 2,851 & 13,538 \\
\hline Information asymmetry measure & -0.1588 & 1.0068 & -0.6617 & -0.3420 & 0.1175 \\
\hline Outside blockholder & 0.2626 & 0.2572 & 0.0000 & 0.1495 & 0.5328 \\
\hline Management blockholder & 0.0805 & 0.1838 & 0.0000 & 0.0000 & 0.0000 \\
\hline Provisions & 0.0239 & 0.0255 & 0.0032 & 0.0158 & 0.0451 \\
\hline Unexpected changes in provisions & -0.0001 & 0.0095 & -0.0027 & -0.0001 & 0.0015 \\
\hline \multicolumn{6}{|c|}{ Panel B: Structure companies $(\mathrm{N}=443)$} \\
\hline Total assets & 1,363 & 2,604 & 261 & 482 & 1,123 \\
\hline Net sales & 1,951 & 3,782 & 337 & 789 & 1,823 \\
\hline Information asymmetry measure & 0.0264 & 0.9199 & -0.4744 & -0.2020 & 0.1862 \\
\hline Outside blockholder & 0.2026 & 0.1732 & 0.0800 & 0.1400 & 0.2941 \\
\hline Management blockholder & 0.0088 & 0.0498 & 0.0000 & 0.0000 & 0.0000 \\
\hline Provisions & 0.0259 & 0.0300 & 0.0053 & 0.0145 & 0.0394 \\
\hline Unexpected changes in provisions & 0.0005 & 0.0097 & -0.0029 & 0.0000 & 0.0024 \\
\hline
\end{tabular}

Notes:

Total assets denote the book value of total assets at fiscal year end (GLD millions); net sales denotes net sales at fiscal year end (GLD millions); the information asymmetry measure denotes the factor scores of the factor analysis on five information asymmetry proxies; outside blockholder denotes the fraction of shares outstanding that is held by the largest blockholder (not being the $\mathrm{CEO}$ ); management blockholder denotes the fraction of shares outstanding that is held by the CEO if he is the largest blockholder; provisions denote the book value of provisions at fiscal year end scaled by lagged total assets; unexpected changes in provisions denote the residuals of the Generalized Least Squares estimation procedure (reported in table 2) scaled by lagged total assets. Data on total assets, net sales and provisions come from the annual reports, stock ownership data come from Het Financieele Dagblad. 


\section{Table 4:}

Abnormal stock returns and analysts' forecast revisions surrounding the announcements of unexpected increases $(\mathrm{N}=222)$ versus unexpected decreases $(\mathrm{N}=264)$ in provisions

\begin{tabular}{lcccccc}
\hline & \multicolumn{2}{c}{$\begin{array}{c}\text { Decreases } \\
\text { in provisions }\end{array}$} & $\begin{array}{c}\text { Increases } \\
\text { in provisions }\end{array}$ & \multicolumn{2}{c}{$\begin{array}{c}\text { Difference } \\
\text { (Inc. - Dec.) }\end{array}$} \\
\cline { 2 - 7 } & mean & t-statistic & mean & t-statistic & mean & t-statistic \\
\hline Panel A: Average abnormal stock returns \\
Day -2 & 0.0526 & 0.74 & 0.0618 & 0.75 & 0.0092 & 0.08 \\
Day -1 & 0.3464 & $3.94^{\dagger}$ & 0.2215 & $2.06^{\ddagger}$ & -0.1249 & -0.91 \\
Day 0 & 0.2306 & 1.48 & 0.6895 & $3.83^{\dagger}$ & 0.4589 & $1.94^{*}$ \\
Day +1 & 0.0327 & 0.25 & 0.3845 & $2.13^{\ddagger}$ & 0.3518 & 1.58 \\
Day +2 & -0.0500 & -0.60 & 0.0140 & 0.16 & 0.0640 & 0.53 \\
\multicolumn{7}{c}{} \\
Panel B: Cumulative abnormal stock returns & & \\
Days (-2,+2) & 0.6120 & $2.50^{\ddagger}$ & 1.3713 & $4.31^{\dagger}$ & 0.7593 & $1.89^{*}$ \\
Days (-1,+1) & 0.6097 & $2.76^{\dagger}$ & 1.2955 & $4.50^{\dagger}$ & 0.6858 & $1.89^{*}$ \\
Days (0,+1) & 0.2633 & 1.21 & 1.0740 & $3.96^{\dagger}$ & 0.8107 & $2.33^{\ddagger}$ \\
Panel C: Analysts' abnormal forecast revisions & & \\
Month 0 & 0.0655 & 0.31 & 0.5312 & $1.81^{*}$ & 0.4657 & 1.28 \\
Months (0,+1) & 0.3829 & 0.98 & 0.9474 & $2.88^{\dagger}$ & 0.5645 & 1.08 \\
Months (0,+3) & 0.0970 & 0.27 & 0.7561 & $2.64^{\dagger}$ & 0.6591 & 1.43 \\
\hline
\end{tabular}

Notes:

This table shows the abnormal stock returns and analysts' abnormal revisions when companies announce unexpected increases in provisions $(\mathrm{N}=222)$ or unexpected decreases in provisions $(\mathrm{N}=264)$. The sixth column reports differences between the mean abnormal stock returns or abnormal forecast revisions of the two groups (unexpected increases in provisions minus unexpected decreases in provisions). I removed 85 firm-year observations from the sample of 571 firm-year observations because of zero changes in provisions.

$\dagger, \ddagger, *$ Significant at the two-tailed $0.01,0.05$ and 0.10 alpha level, respectively. 


\section{Table 5:}

Cumulative abnormal stock returns and abnormal forecast revisions in post-event period and pre-event period

\begin{tabular}{|c|c|c|c|c|c|c|}
\hline & \multicolumn{2}{|c|}{$\begin{array}{c}\text { Decrease } \\
\text { in provisions }\end{array}$} & \multicolumn{2}{|c|}{$\begin{array}{c}\text { Increase } \\
\text { in provisions }\end{array}$} & \multicolumn{2}{|c|}{$\begin{array}{c}\text { Difference } \\
\text { (Inc. - Dec.) }\end{array}$} \\
\hline & mean & t-statistic & mean & t-statistic & mean & t-statistic \\
\hline \multicolumn{7}{|c|}{ Panel A: Abnormal stock returns } \\
\hline Days $(-12,-3)$ & 0.5317 & $2.16^{\ddagger}$ & 0.7622 & $3.02^{\dagger}$ & 0.2305 & 0.65 \\
\hline Days $(+3,+12)$ & 0.0889 & 0.35 & 0.2586 & 1.09 & 0.1697 & 0.48 \\
\hline \multicolumn{7}{|c|}{ Panel B: Analysts' abnormal forecast revisions } \\
\hline Months $(-6,-4)$ & -0.1579 & -1.04 & 0.2854 & 1.50 & 0.4433 & $1.82^{*}$ \\
\hline Months $(+4,+6)$ & -0.3580 & -1.01 & -0.6020 & -1.27 & -0.2440 & -0.42 \\
\hline
\end{tabular}

Notes:

This table shows the abnormal stock returns and analysts' abnormal revisions prior to and after companies' announcement unexpected increases in provisions $(\mathrm{N}=222)$ or unexpected decreases in provisions $(\mathrm{N}=264)$. The sixth column reports differences between the mean abnormal stock returns or abnormal forecast revisions of the two groups (unexpected increases in provisions minus unexpected decreases in provisions). I removed 85 firm-year observations from the sample of 571 firm-year observations because of zero changes in provisions.

$\dagger, \ddagger, *$ Significant at the two-tailed $0.01,0.05$ and 0.10 alpha level, respectively. 


\section{Table 6:}

Regression analysis abnormal stock returns and abnormal revisions

\begin{tabular}{lcccccc}
\hline & \multicolumn{3}{c}{ Abnormal returns } & \multicolumn{3}{c}{ Abnormal revisions } \\
\cline { 2 - 7 } Independent variable & $S C$ & NSC & NSC-SC & SC & NSC & NSC-SC \\
\hline Intercept & 0.0042 & 0.0017 & -0.0025 & 0.0012 & 0.0030 & 0.0018 \\
& $(3.75)^{\dagger}$ & $(0.96)$ & $(-1.17)$ & $(4.05)^{\dagger}$ & $(3.05)^{\dagger}$ & $(2.32)^{\ddagger}$ \\
$\Delta \mathrm{E}$ & 0.0496 & 0.0379 & -0.0116 & 0.0059 & -0.0160 & -0.0219 \\
& $(1.54)$ & $(0.64)$ & $(-0.17)$ & $(1.92)^{*}$ & $(-0.69)$ & $(-1.26)$ \\
$\mathrm{UP}$ & 0.2998 & 0.9880 & 0.6880 & 0.0829 & 0.3214 & 0.2385 \\
& $(2.27)^{\ddagger}$ & $(3.11)^{\dagger}$ & $(1.95)^{*}$ & $(2.07)^{\ddagger}$ & $(2.62)^{\dagger}$ & $(2.38)^{\ddagger}$ \\
INFOASYM & 0.0007 & 0.0028 & 0.0022 & 0.0015 & 0.0031 & 0.0017 \\
& $(0.39)$ & $(1.60)$ & $(0.88)$ & $(3.24)^{\dagger}$ & $(2.96)^{\dagger}$ & $(1.81)^{*}$ \\
INFOASYM*UP & 0.1817 & 1.1936 & 1.0119 & 0.1164 & 0.3249 & 0.2085 \\
& $(0.78)$ & $(3.26)^{\dagger}$ & $(2.29)^{\ddagger}$ & $(1.84)^{*}$ & $(2.60)^{\ddagger}$ & $(1.79)^{*}$ \\
& & & & & & \\
$\mathrm{~N}$ & 443 & 128 & - & 443 & 128 & - \\
adj. $R^{2}$ & $1.52 \%$ & $8.36 \%$ & - & $3.71 \%$ & $6.69 \%$ & - \\
F-value & $2.703^{\ddagger}$ & $3.898^{\dagger}$ & & $5.262^{\dagger}$ & $3.276^{\ddagger}$ & \\
\hline
\end{tabular}

Notes:

$\Delta \mathrm{E}$ denotes the annual change in reported earnings before adjustments to provisions scaled by lagged total assets, UP denotes the unexpected change in provisions scaled by lagged total assets and INFOASYM denotes the level of the information asymmetry measure. Column SC (NSC) shows the parameter estimates for structure companies (non-structure companies). Column NSC-SC shows the differences between parameter estimates for non-structure companies and parameter estimates for structure companies. T-statistics are in parentheses.

T-statistics of differences between parameters $\beta_{i}^{a}$ of model $a$ and parameters $\beta_{i}^{b}$ of model $b$ are calculated as follows:

in which:

$$
t_{i}^{\text {diff }}=\frac{\beta_{i}^{a}-\beta_{i}^{b}}{\left[\operatorname{Var}\left(\epsilon^{a b}\right)\right]^{0.5}\left[\operatorname{Var}\left(b_{i}^{a}\right) / \operatorname{Var}\left(\epsilon^{a}\right)+\operatorname{Var}\left(b_{i}^{b}\right) / \operatorname{Var}\left(\epsilon^{b}\right)\right]^{0.5}}
$$

$$
\operatorname{Var}\left(\epsilon^{a b}\right)=\frac{\left(n^{a}-k^{a}-1\right) \operatorname{Var}\left(\epsilon^{a}\right)+\left(n^{b}-k^{b}-1\right) \operatorname{Var}\left(\epsilon^{b}\right)}{n^{a}+n^{b}-k^{a}-k^{b}-2}
$$

and $\operatorname{Var}\left(b_{i}^{a}\right)$ denotes the estimated variance of parameter estimate $b_{i}^{a}, \operatorname{Var}\left(\epsilon^{a}\right)$ denotes the mean squared error of model a, $n^{a}$ equals the number of observations used to estimate model $a$ and $k^{a}$ equals the number of estimated parameters of model $a$.

$\dagger, \ddagger, *$ Significant at the two-tailed $0.01,0.05$ and 0.10 alpha level, respectively. 


\section{Table 7:}

Regression analysis abnormal stock returns and abnormal revisions with governance control variables

\begin{tabular}{lcccccc}
\hline & \multicolumn{3}{c}{ Abnormal returns } & \multicolumn{3}{c}{ Abnormal revisions } \\
\cline { 2 - 7 } Independent variable & $S C$ & NSC & NSC-SC & $S C$ & NSC & NSC-SC \\
\hline Intercept & 0.0042 & 0.0024 & -0.0018 & 0.0012 & 0.0030 & 0.0018 \\
& $(3.74)^{\dagger}$ & $(1.40)$ & $(-0.83)$ & $(4.15)^{\dagger}$ & $(2.94)^{\dagger}$ & $(2.17)^{\ddagger}$ \\
$\Delta \mathrm{E}$ & 0.0460 & 0.0651 & 0.0191 & 0.0057 & -0.0162 & -0.0219 \\
& $(1.42)$ & $(1.10)$ & $(0.27)$ & $(1.85)^{*}$ & $(-0.69)$ & $(-1.26)$ \\
$\mathrm{UP}$ & 0.0104 & 1.9048 & 1.8945 & -0.0426 & 0.4959 & 0.5386 \\
& $(0.03)$ & $(2.37)^{\ddagger}$ & $(2.10)^{\ddagger}$ & $(-0.43)$ & $(2.32)^{\ddagger}$ & $(2.79)^{\dagger}$ \\
INFOASYM & 0.0005 & 0.0034 & 0.0028 & 0.0015 & 0.0031 & 0.0016 \\
& $(0.31)$ & $(1.93)^{*}$ & $(1.14)$ & $(3.32)^{\dagger}$ & $(2.92)^{\dagger}$ & $(1.74)^{*}$ \\
INFOASYM*UP & 0.0435 & 1.4534 & 1.4099 & 0.0397 & 0.4327 & 0.3929 \\
& $(0.17)$ & $(3.52)^{\dagger}$ & $(2.82)^{\dagger}$ & $(0.48)$ & $(2.83)^{\dagger}$ & $(2.67)^{\dagger}$ \\
OUTBLOCK*UP & -0.0210 & -1.8366 & -1.8156 & 0.2961 & -0.3551 & -0.6512 \\
& $(-0.03)$ & $(-2.14)^{\ddagger}$ & $(-1.56)$ & $(1.31)$ & $(-1.62)$ & $(-2.13)^{\ddagger}$ \\
MANBLOCK*UP & 1.1016 & 7.6153 & 6.5138 & 0.0979 & -1.1871 & -1.2850 \\
& $(0.83)$ & $(1.70)^{*}$ & $(1.34)$ & $(0.22)$ & $(-0.64)$ & $(-0.90)$ \\
SUPEXEC*UP & 0.1057 & -0.1271 & -0.2328 & 0.0240 & 0.0312 & 0.0072 \\
& $(0.97)$ & $(-0.43)$ & $(-0.71)$ & $(0.87)$ & $(0.37)$ & $(0.11)$ \\
& & & & & & \\
$\mathrm{N}$ & 443 & 128 & - & 443 & 128 & - \\
adj. $R^{2}$ & $1.39 \%$ & $12.64 \%$ & - & $3.51 \%$ & $6.69 \%$ & - \\
F-value & $1.887^{*}$ & $3.624^{\dagger}$ & & $3.296^{\dagger}$ & $2.301^{\ddagger}$ & \\
\hline
\end{tabular}

Notes:

OUTBLOCK denotes the fraction of common shares outstanding held by the largest blockholder (not being management), MANBLOCK denotes the fraction of common shares outstanding held by the CEO if he is the largest blockholder, SUPEX denotes the ratio of the number of supervisors and the number of executives. Column SC (NSC) shows the parameter estimates for structure companies (non-structure companies). Column NSC-SC shows the differences between parameter estimates for non-structure companies and parameter estimates for structure companies. T-statistics are in parentheses.

$\dagger, \ddagger, *$ Significant at the two-tailed $0.01,0.05$ and 0.10 alpha level, respectively. 


\section{Table 8:}

Differences between parameter estimates of structure companies and non-structure companies $(N S C-S C)$ of regression analyses with alternative return and revision intervals

\begin{tabular}{lcccc}
\hline \multirow{2}{*}{ Independent variable } & \multicolumn{2}{c}{ Abnormal returns } & \multicolumn{2}{c}{ Abnormal revisions } \\
\cline { 2 - 5 } & Days $(-1,+1)$ & Days $(-2,+2)$ & Month 0 & Months $(0,+3)$ \\
\hline Intercept & -0.0022 & -0.0009 & -0.0003 & 0.0011 \\
& $(-1.46)$ & $(-0.89)$ & $(-0.62)$ & $(1.62)$ \\
$\mathrm{E}$ & -0.0052 & -0.0075 & 0.0101 & -0.170 \\
& $(-0.11)$ & $(-0.23)$ & $(0.90)$ & $(-1.11)$ \\
$\mathrm{UP}$ & 0.4438 & 0.1829 & 0.1302 & 0.0369 \\
& $(1.80)^{*}$ & $(1.12)$ & $(2.01)^{\ddagger}$ & $(0.42)$ \\
INFOASYM & 0.0017 & 0.0006 & -0.0003 & 0.0009 \\
& $(0.97)$ & $(0.52)$ & $(-0.50)$ & $(1.14)$ \\
INFOASYM*UP & 0.6635 & 0.3401 & 0.1404 & -0.0526 \\
& $(2.16)^{\ddagger}$ & $(1.66)$ & $(1.86)^{*}$ & $(-0.51)$ \\
\hline
\end{tabular}

$\dagger, \ddagger, *$ Significant at the two-tailed $0.01,0.05$ and 0.10 alpha level, respectively. 